\title{
Novel TLR7 agonist stimulates activity of CIK/NK immunological effector cells to enhance antitumor cytotoxicity
}

\author{
DONG GAO $^{1 *}$, YONGGUANG CAI ${ }^{2 *}$, YANYUAN CHEN $^{1}$, WANG LI $^{1}$, \\ CHIH-CHANG WEI ${ }^{1}$, XIAOLING LUO ${ }^{1}$ and YUHUAN WANG ${ }^{1}$ \\ ${ }^{1}$ Shenzhen Hornetcorn Biotechnology Co., Ltd., Shenzhen, Guangdong 518045; ${ }^{2}$ The Fifth District of Chemotherapy, \\ Department of Medical Oncology, Central Hospital of Guangdong Provincial \\ Agricultural Reclamation, Zhanjiang, Guangdong 524002, P.R. China
}

Received May 19, 2016; Accepted March 21, 2017

DOI: 10.3892/ol.2018.7954

\begin{abstract}
Toll-like receptor (TLR) 7/8 agonists have been applied in combination with chemo-, radio- or immunotherapy for lymphoma, and used as topical drugs for the treatment of viral skin lesions and skin tumors. In the present study, the role of an adenine analog, 9-(4-carboxyphenyl)-8-hydroxy-2-(2-me thoxyethoxy)-adenine [termed Gao Dong (GD)], a novel TLR7 agonist, in the activation of cytokine-induced killer/natural killer $(\mathrm{CIK} / \mathrm{NK})$ cells was determined. The results of the present study indicated that GD was able to activate $\mathrm{CIK} / \mathrm{NK}$ cells. The proportion of GD-induced $\mathrm{CD} 3{ }^{+} \mathrm{CD} 56^{+} \mathrm{CIK}$ and $\mathrm{CD}^{-} \mathrm{CD}^{-} 6^{+} \mathrm{NK}$ cells was $\sim 4 \%$ higher respectively compared with the control. Notably, combination therapy with $\mathrm{CIK} / \mathrm{NK}$ cells stimulated by GD, markedly suppressed the proliferation of the chronic myelogenous leukemia K562 cell line. Following GD treatment, the cytotoxicity improved by $\sim 25$ and $21 \%$ when the effector/target ratio was 20:1 and 10:1, respectively. The results of the present study suggested a novel protocol for $\mathrm{CIK} / \mathrm{NK}$ cell proliferation and revealed that GD may serve as a potent innate and adaptive immunomodulator in immunocyte culture.
\end{abstract}

\section{Introduction}

Adoptive cells, including cytokine-induced killer (CIK) and natural killer (NK) cells, aimed at inducing or boosting efficient immune responses have exhibited efficacy and safety in clinical trials (1-6). A typical obstacle to the successful application of these treatments is the difficulty of generating

Correspondence to: $\mathrm{Dr}$ Dong Gao, Shenzhen Hornetcorn Biotechnology Co., Ltd., 14 Shihua Road, Shenzhen, Guangdong 518045, P.R. China

E-mail: gaodong5211@126.com

*Contributed equally

Key words: cytokine-induced killer cells, natural killer cells, Toll-like receptor 7, cytotoxicity, combination therapy clinically relevant numbers of CIK/NK cells (7). A previous study has demonstrated that immunomodulators may boost the number of immune effector cells and prime their activity efficiently (8). Toll-like receptor (TLR) 7 is expressed in T, CIK and NK cells, in addition to antigen-presenting cells (9). TLR-mediated combination therapies are becoming attractive approaches due to the low toxic side effects and high activity in physiological homeostasis that they exhibit. A phase II clinical study was established in which a TLR9 agonist (CpG ODN1018 ISS) was used with rituximab to treat follicular lymphoma (10). Systemic administration of a synthetic TLR7 agonist (R848) combined with radiation may prime a cytotoxic $\mathrm{T}$ cell response against lymphoma cells, and prime a memory immune response that may prevent recurrence of lymphoma (11). Enhanced antitumor efficacy was also identified when the TLR9 agonist (CpG ODN1826) was combined with radio- and chemotherapy (12). These previous studies led to the present study which aimed at determining the role of the TLR7 agonist in the activation of adoptive cells, including CIK and NK cells.

A protocol has been established previously to rapidly and reproducibly expand CIK cells in vitro from human peripheral blood (13-16). In the present study, 9-(4-carboxyphenyl)8-hydroxy-2-(2-methoxyethoxy)-adenine (termed Gao Dong, GD) (17), a novel TLR7 agonist, was combined with the traditional protocol of culturing CIK cells to determine the role of GD in the activation of CIK/NK cells. The results of the present study demonstrated that GD may activate CIK/NK cells. Notably, the combination therapy with CIK/NK cells, stimulated by GD, markedly suppressed the proliferation of the chronic myelogenous leukemia K562 cell line. The results of the present study suggested a novel protocol for CIK/NK cell proliferation and indicated that GD may serve as a potent innate and adaptive immunomodulator in immunocyte culture. This novel combination therapy concept may be a solution to the difficulty of chemotherapy and adoptive immunotherapy.

\section{Materials and methods}

Cell culture media and reagents. RPMI-1640 serum-free medium (Gibco; Thermo Fisher Scientific, Inc., Waltham, MA, USA) was used with $10 \%$ fetal bovine serum (Gibco; Thermo 
Fisher Scientific, Inc.). CIK/NK cells ( $1 \times 10^{6}$ cells/ml, Pierce; Thermo Fisher Scientific, Inc.) were generated and cultured with $80 \mathrm{U} / \mathrm{ml}$ gentamycin. Human recombinant interleukin (IL)-2, $\geq 1,000 \mathrm{U} / \mathrm{ml}$, was purchased from Beijing ShuangLu Pharmaceutical Co., Ltd. (Beijing, China). GD (Fig. 1), synthesized in our laboratory, was added to the cell culture medium at a concentration of $5 \mu \mathrm{M}$.

Cell culture and quantification. The control CIK cells were generated as follows: Human peripheral blood mononuclear cells (PBMCs) from three donors were isolated by density gradient centrifugation at $4^{\circ} \mathrm{C}$ at $700 \mathrm{x}$ g for $20 \mathrm{~min}$ using Ficoll (Takeda Pharmaceutical Company, Ltd., Tokyo, Japan). The cells were grown in AIM-V serum-free medium (Gibco; Thermo Fisher Scientific, Inc.) which consisted of 5\% autologous plasma and $80 \mathrm{U} / \mathrm{ml}$ gentamycin. A total of 1,000 U/ml human recombinant interferon- $\gamma$ (Gene Tech Co., Ltd., Hong Kong, China) were added on day 0 . After $24 \mathrm{~h}$ of incubation at $37^{\circ} \mathrm{C}$, $50 \mathrm{ng} / \mathrm{ml}$ OKT3 antibody (cat. no. 555339) against cluster of differentiation (CD)3 (Ortho Biotech, Inc., Raritan, NJ, USA), $100 \mathrm{U} / \mathrm{ml} \mathrm{IL-1}$ (Genzyme, Cambridge, MA, USA) and $300 \mathrm{U} / \mathrm{ml}$ IL-2 (Genzyme) were added. Cells were incubated at $37^{\circ} \mathrm{C}$ in a humidified atmosphere containing $5 \% \mathrm{CO}_{2}$ and were subcultured every 3 days in fresh AIM-V with the addition of 5\% auto serum and $1,000 \mathrm{U} / \mathrm{ml} \mathrm{IL-2}$ at $1 \times 10^{6}$ cells $/ \mathrm{ml}$.

The harvested PBMCs from each donor were divided into three equally and treated as follows: One group was cultured following the protocol as aforementioned and termed 'none' (the control group); another received the addition of GD with IFN- $\gamma$ on day 0 and was termed group '+GD'; and the third group received GD only and on day 0 , was termed group '+GD-IFN- $\gamma$ '.

Cell numbers were counted using the Cell Coulter Technique (Z2 Coulter; Coulter Electronics, Ltd., Luton, UK) on days $0,3,5,7,9$ and 15 . Cell viability was analyzed using the trypan blue dye exclusion assay at each time point. Trypan blue dye-exclusion assay was performed by adding $20 \mu 10.4 \%$ dye solution, and live (unstained) and dead (stained) cells were counted under Leica inverted microscope DMil (x10 magnification; Leica Microsystems GmbH, Wetzlar, Germany). Five random microscopic fields were counted in each sample. A total of 300 cells were counted per sample. Non-viable cells were detected as those which took up dye. Written informed consent was obtained from all human donors of PBMCs, and the present study received ethical approval by Shenzhen University Health Science Center Medical Ethics Committee (Shenzhen, China).

Analyses of lymphocyte subsets. Cell cultures were prepared for flow cytometric phenotypic analysis and four-color fluorescence was performed according to standard procedures (16). Briefly, $10^{5} \mathrm{CIK}$ cells derived from PBMCs of donors suspended in $50 \mu \mathrm{l}$ PBS were stained with $10 \mu \mathrm{l}$ fluorochrome-conjugated monoclonal antibodies (1:50; BD Biosciences, Franklin Lakes, NJ, USA) against CD3 (cat. no. 561809), CD4 (cat. no. 561841), CD8 (cat. no. 566451, all T-cell antigens) and CD56 (cat. no. 557747, NK-cell antigen). Following the addition of the primary antibody, cells were incubated for $20 \mathrm{~min}$ at room temperature and subsequently washed with PBS. Phenotype analysis was carried out using an Accuri C6 flow cytometer

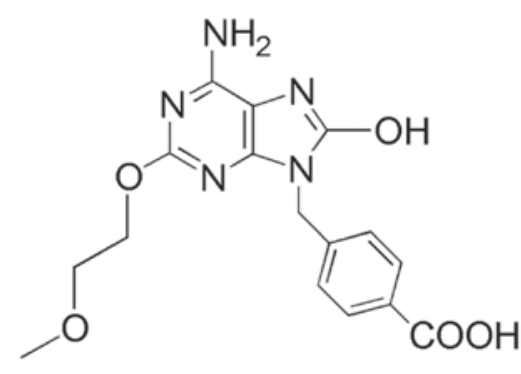

Figure 1. Molecular structure of GD, 9-(4-carboxyphenyl)-8-hydroxy-2(2-methoxyethoxy)-adenine.

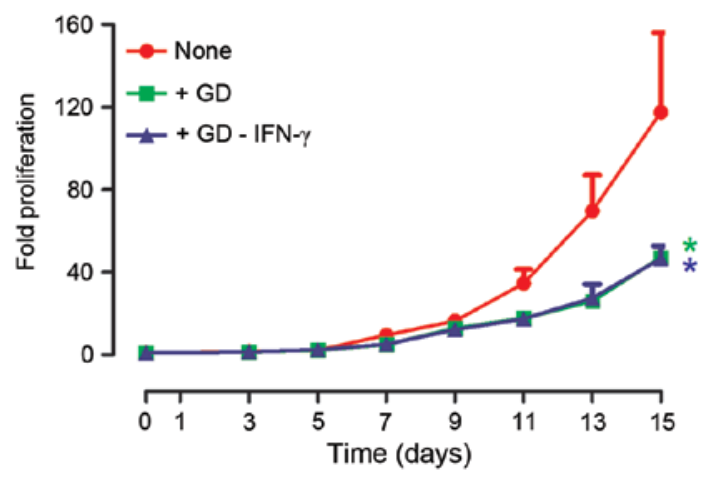

Figure 2. Cell proliferation following three distinct treatments of peripheral blood mononuclear cells derived from three human donors. " $\mathrm{P}<0.05$, vs. 'none'. GD, 9-(4-carboxyphenyl)-8-hydroxy-2-(2-methoxyethoxy)-adenine; IFN- $\gamma$, interferon- $\gamma$.

(BD Biosciences). The data were analyzed using BD CellQuest Pro Software (version 5.1, BD Biosciences).

Cell-mediated cytotoxicity. Cells from the three donors were analyzed on day 15 following culture and the K562 cell line was used as the target. Cell viability of K562 cells was evaluated in vitro using a Cell Counting Kit-8 (CCK-8). K652 cells were seeded in triplicate in 96-well plates $\left(2 \times 10^{4}\right.$ cells/well) and CIK/NK cells were added at ratios of effector to target of 5:1, 10:1 and 20:1. Following incubation for $18 \mathrm{~h}$ at $37^{\circ} \mathrm{C}$ in a humidified atmosphere containing $5 \% \mathrm{CO}_{2}, 20 \mu \mathrm{l} \mathrm{CCK-8}$ was added to each well prior to incubation for $4 \mathrm{~h}$ at $37^{\circ} \mathrm{C}$.

The absorbance of each well was determined with an ELISA reader (iMark; Bio-Rad Laboratories, Inc., Hercules, CA, USA) at a wavelength of $450 \mathrm{~nm}$. Cytotoxicity (\%) was calculated using the following equation:

$$
\text { Cytotoxicity }(\%)=\left[1-\frac{\mathrm{A} 450(\text { effector }+ \text { target })-\mathrm{A} 450(\text { effector control })}{\mathrm{A} 450(\text { target control })}\right] \times 100
$$

Statistical analysis. Statistical significance was analyzed using Student's t-test using Prism software version 4.0c (GraphPad Software, Inc., La Jolla, CA, USA). P $<0.05$ was considered to indicate a statistically significant difference.

\section{Results}

Cell proliferation rates. After 15 days, the proliferation rates of cells were increased 127-fold (median; range, 45-178), 46-fold 

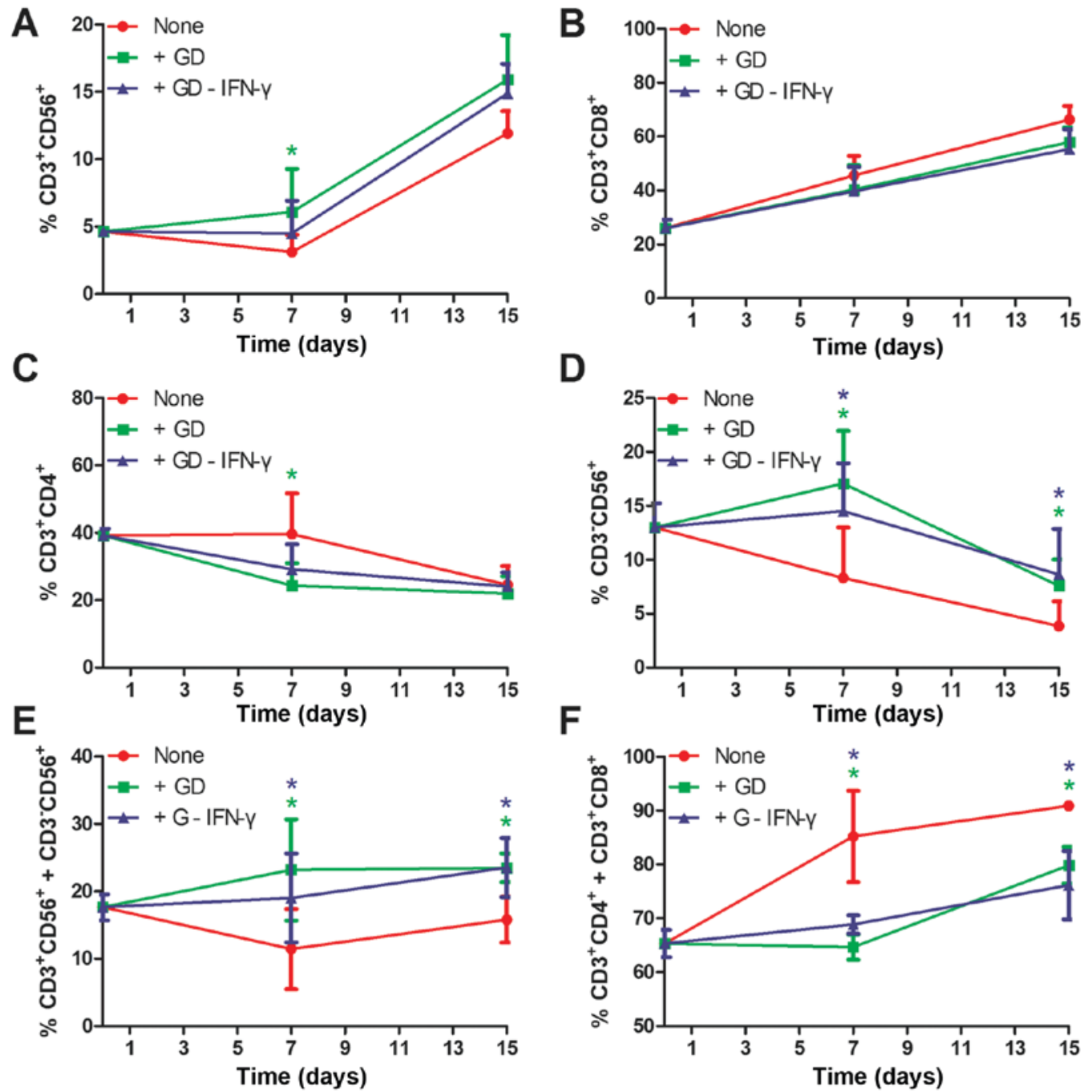

Figure 3. (A-F) Proportions of CIK, NK and T cells on days 0, 7 and 15 of culture. "P<0.05, vs. 'none'. GD, 9-(4-carboxyphenyl)-8-hydroxy-2-(2-methoxyethoxy)adenine; IFN- $\gamma$, interferon- $\gamma$; CIK, cytokine-induced killer; NK, natural killer.

(median; range, 43-53) and 45-fold (median; range, 37-57) in group 'none', '+GD' and '+GD-IFN- $\gamma$ ', respectively (Fig. 2). The results of the present study indicate that GD decreased the range of proliferation rates from different donors. Thus, the protocol of the present study may yield relatively uniform CIK/NK cells that may standardize CIK/NK cells.

Effect of GD on the phenotype of CIK/NK cells. As presented in Figs. 3 and 4, the proportions of $\mathrm{CD}^{+} \mathrm{CD} 56^{+} \mathrm{CIK}$ cells (Fig. 3A) and $\mathrm{CD}^{+}{ }^{+} \mathrm{CD} 8^{+} \mathrm{T}$ cells (Fig. 3B) increased over the 15-day period. However, for the $\mathrm{CD}^{+} \mathrm{CD}^{+}{ }^{+} \mathrm{T}$ cells (Fig. 3C) and CD3 ${ }^{-}$CD56 $6^{+}$NK cells (Fig. 3D), the proportions decreased over the 15-day period. Furthermore, the proportions of GD-induced CIK cells and NK cells were $~ 4 \%$ higher compared with the control $(15.9 \pm 5.8$ vs. $11.9 \pm 2.9$ and $7.6 \pm 4.2$ vs. 3.8 \pm 3.7 , respectively; Fig. 3A and D; Fig. 4). Additionally, the proportions of $\mathrm{GD}$-induced $\mathrm{CD} 3{ }^{+} \mathrm{CD} 4{ }^{+} \mathrm{T}$ cells and $\mathrm{CD}^{+} \mathrm{CD}^{+}$cells were $\sim 9 \%$ and $3 \%$ lower compared with the control, respectively (Fig. 3B and C; Fig. 4). Notably, there were significant differences between GD treatment and none, or between GD-IFN- $\gamma$ treatment and none at days 7 and 15 , when effector cells (CIK/NK) and other cells were considered (Fig. 3E and F). Treatment with GD may be able to counteract the IFN- $\gamma$-stimulated function in CIK culture, which was confirmed by data collected from the '+GD-IFN- $\gamma$ ' group (Figs. 3 and 4). A notable inter-donor difference was that the final proportions of CIK and NK cells yield were linearly dependent on their initial numbers (data not shown).

Enhancement of cytotoxic capacity of CIK/NK cells stimulated by $G D$. The killing rates were notably increased in the '+GD' and '+GD-IFN- $\gamma$ ' groups compared with the control group $(\mathrm{P}<0.05$; Fig. 5). The killing rates for group ' + GD' vs. group 'none' were $98.9 \pm 2.4$ vs. $74.4 \pm 12.0,54.0 \pm 15.3$ vs. $32.8 \pm 21.5$ and $28.0 \pm 27.2$ vs. $26.3 \pm 26.3 \%$, respectively. Killing rates of group ' $+\mathrm{GD}-\mathrm{IFN}-\gamma$ ' vs. group 'none' were $89.0 \pm 4.2$ vs. $74.4 \pm 12.0,48.7 \pm 16.6$ vs. $32.8 \pm 21.5$ and $34.6 \pm 26.8$ vs. $26.3 \pm 26.3 \%$, at effector/target ratios of $20: 1$, 10:1 and 5:1, respectively. The results of the present study indicate that GD induced a marked cytotoxic effect of CIK/NK cells on K562 cells.

\section{Discussion}

CIK cells are a heterogeneous subset of lymphocytes generated by incubating PBMCs with various cytokines in vivo. CIK and NK cells in CIK culture systems are important antitumor 
Day 0
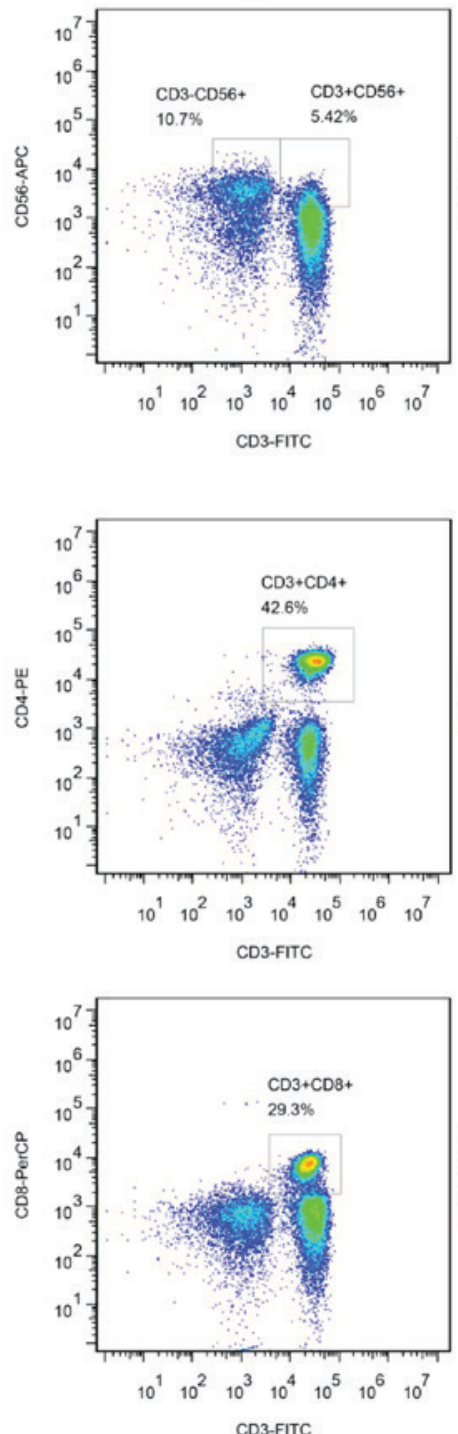

Day 7
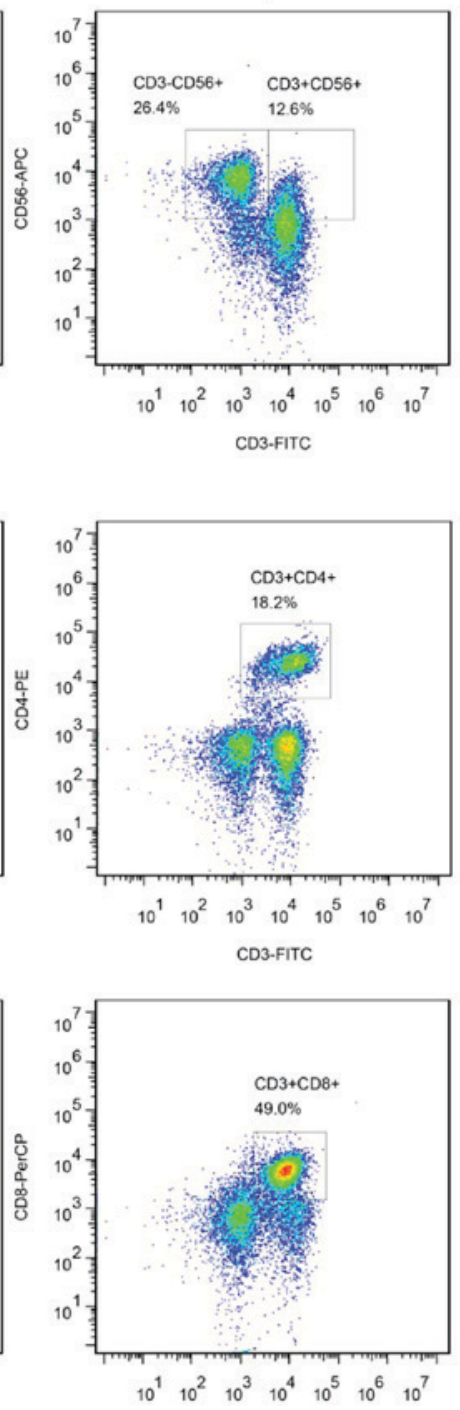

CD3-FITC
Day 15
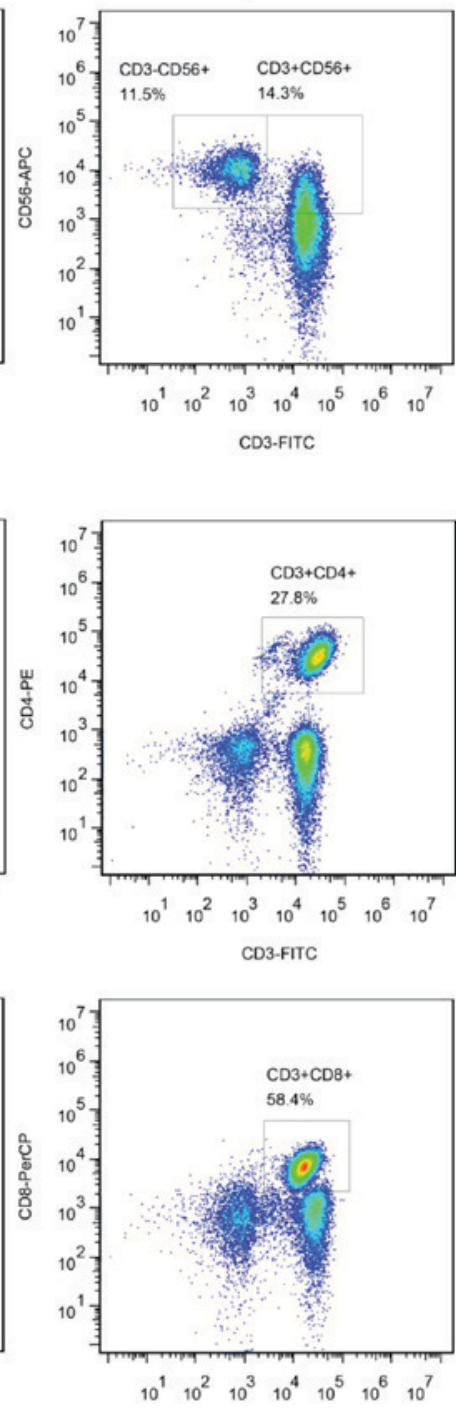

CD3-FITC

Figure 4. Phenotype of CIK, NK and T-cells in group '+GD' on days 0, 7 and 15 of culture. Results are representative of three experiments. CIK, cytokine-induced killer; NK, natural killer; GD, 9-(4-carboxyphenyl)-8-hydroxy-2-(2-methoxyethoxy)-adenine; FITC, fluorescein isothiocyanate; CD, cluster of differentiation; APC, allophycocyanin; PE, phycoerythrin; PerCP, peridinin chlorophyll protein complex.

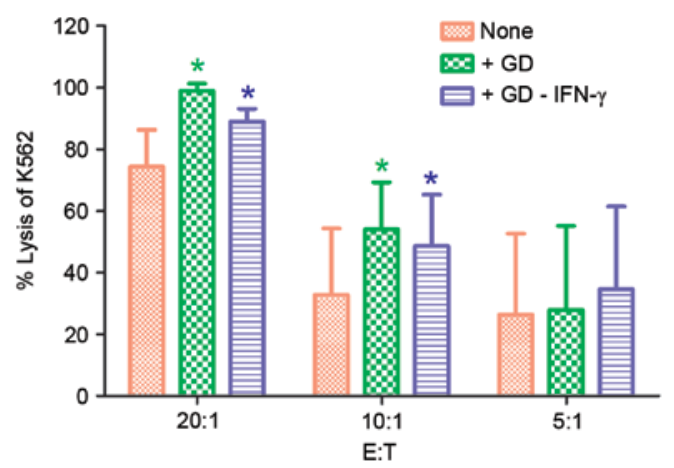

Figure 5. Cytotoxicity of CIK/NK cells towards the K562 cell line. ${ }^{*} \mathrm{P}<0.05$, vs. 'none'. GD, 9-(4-carboxyphenyl)-8-hydroxy-2-(2-methoxyethoxy)-adenine; IFN- $\gamma$, interferon- $\gamma$; CIK, cytokine-induced killer; NK, natural killer; E:T, effector/target ratio.

effectors in immunotherapy (18). Culture systems used to provide adequate numbers of immune cells have focused primarily on stimulation with more effective cytokine and monoclonal antibodies $(19,20)$. To the best of our knowledge, existing methods used for expanding CIK cells were almost negative with regard to expanding NK cells, but provided a high ratio of $\mathrm{CD}^{+} \mathrm{CD}^{+} \mathrm{T}$ cells $(21)$. Excessive $\mathrm{CD}^{+}{ }^{+} \mathrm{CD} 8^{+} \mathrm{T}$ cell numbers are not beneficial for eliminating tumor cells; however, they increase the risk of graft-versus-host disease $(22,23)$. Thus, a method in which CIK/NK cells expand synchronously and $\mathrm{CD}^{+} \mathrm{CD}^{+} \mathrm{T}$ cells proliferation decreases, may be valuable, economical and practical for clinical application.

TLR7 agonists are effective immunomodulators as they directly promote the activation of T, CIK and NK cells, induce tumor cell apoptosis or sensitize tumor cells to be killed by cytotoxic T lymphocytes and NK cells (24). CIK/NK cells alone and in combination with other therapies, including TLR7/8 agonists and imidazoquinoline analogs, are proven to be useful and safe (10-12). In the present study, the activity of the TLR7 agonist GD for the proliferation of CIK was determined for the first time, to the best of 
our knowledge. The results indicated that GD significantly promoted the proliferative capacity of CIK/NK and decreased the proliferative capacity of no-CIK/NK cells, including $\mathrm{CD}^{+} \mathrm{CD}^{+}$and $\mathrm{CD}^{+} \mathrm{CD}^{+} \mathrm{T}$ cells, compared with the control. Additionally, GD improved the cytotoxic effect of CIK/NK cells on K562 cells. Thus, positive T cell co-stimulation by TLR7/8 ligands is dependent on the cellular environment (25).

TLR7/8 agonists have been demonstrated previously to markedly upregulate IFN- $\gamma$ and IL-12 (26), thus it may be possible to decrease the amount of exogenous IFN- $\gamma$ used in the cell culture, and consequently decrease the toxicity exhibited from exogenous IFN- $\gamma$. It is hypothesized that local expression of IFN- $\gamma$ and IL-12 may be less harmful to the patient than systemic administration of high amounts of IFN- $\gamma$ and IL-12. The results of the '+GD-IFN- $\gamma$ ' group indicated that the local IFN- $\gamma$ is a component of exogenous IFN- $\gamma$ and, notably, the amount of IFN- $\gamma$ secreted by the cells appeared to be sufficient to increase proliferation of $\mathrm{CIK} / \mathrm{NK}$ cells. IL-12 enhances efficacy and decreases the enrichment time in CIK immunotherapy (27). Imidazoquinoline analogs (TLR7/8 agonists) promoted the proliferative capacity of NK cells to enhance antitumor effects (8). The results of the present study indicated a marked increase in the cytotoxic activity at a low ratio of effector to target cells. This appears to be of major importance, as it is difficult to inject patient effector cells at a ratio of 40:1 of effector to target cells in a clinical situation.

The results of the present study have demonstrated for the first time, to the best of our knowledge, that a TLR7 purine agonist promoted the proliferative capacity of CIK/NK cells to enhance antitumor effects. Since GD is involved in immune responses in immunological cell culture in vitro, GD was separated in culture medium while cells were harvested, therefore GD-free cells were reinfused in vivo. This strategy may reduce the risk of toxic cytokine syndrome induced by TLR7 ligands if injected directly in vivo. Furthermore, the heterogeneous cultured cell subset rich in CIK/NK cells and a low proportion of $\mathrm{CD}^{+} \mathrm{CD}^{+} \mathrm{T}$ cells may be valuable in attenuating side effects and may be economical and practical for clinical application. This novel combination therapy concept may be a solution to the problem of chemotherapy and adoptive immunotherapy.

\section{Acknowledgements}

The present study was supported by the Basic Research Program of Shenzhen (grant nos. JCYJ20130326110139687, JSGG20160226161357949 and CXZZ20140509144527788) and the China Postdoctoral Science Foundation (grant no. 2014M552234).

\section{References}

1. Rosenberg SA, Restifo NP, Yang JC, Morgan RA and Dudley ME: Adoptive cell transfer: A clinical path to effective cancer immunotherapy. Nat Rev Cancer 8: 299-308, 2008.

2. Schmeel FC, Schmeel LC, Gast SM and Schmidt-Wolf IG: Adoptive immunotherapy strategies with cytokine-induced killer (CIK) cells in the treatment of hematological malignancies. Int J Mol Sci 15: 14632-14648, 2014.

3. Chung MJ, Park JY, Bang S, Park SW and Song SY: Phase II clinical trial of ex vivo-expanded cytokine-induced killer cells therapy in advanced pancreatic cancer. Cancer Immunol Immunother 63: 939-946, 2014.
4. Yu X, Zhao H, Liu L, Cao S, Ren B, Zhang N, An X, Yu J, Li H and Ren X: A randomized phase II study of autologous cytokine-induced killer cells in treatment of hepatocellular carcinoma. J Clin Immunol 34: 194-203, 2014.

5. Pérez-Martínez A, Fernández L, Valentín J, Martínez-Romera I, Corral MD, Ramírez M, Abad L, Santamaría S, GonzálezVicent M, Sirvent S, et al: A phase I/II trial of interleukin-15-stimulated natural killer cell infusion after haplo-identical stem cell transplantation for pediatric refractory solid tumors. Cytotherapy 17: 1594-1603, 2015.

6. Sakamoto N, Ishikawa T, Kokura S, Okayama T, Oka K, Ideno M, Sakai F, Kato A, Tanabe M, Enoki T, et al: Phase I clinical trial of autologous NK cell therapy using novel expansion method in patients with advanced digestive cancer. J Transl Med 13: 277, 2015.

7. Bonanno G, Iudicone P, Mariotti A, Procoli A, Pandolfi A, Fioravanti D, Corallo M, Perillo A, Scambia G, Pierelli L and Rutella S: Thymoglobulin, interferon- $\gamma$ and interleukin-2 efficiently expand cytokine-induced killer (CIK) cells in clinical-grade cultures. J Transl Med 8: 129, 2010.

8. Zhou Z, Yu X, Zhang J, Tian Z and Zhang C: TLR7/8 agonists promote NK-DC cross-talk to enhance NK cell anti-tumor effects in hepatocellular carcinoma. Cancer Lett 369: 298-306, 2015.

9. Smits EL, Ponsaerts P, Berneman ZN and Van Tendeloo VF: The use of TLR7 and TLR8 ligands for the enhancement of cancer immunotherapy. Oncologist 13: 859-875, 2008.

10. Friedberg JW, Kelly JL, Neuberg D, Peterson DR, Kutok JL, Salloum R, Brenn T, Fisher DC, Ronan E, Dalton V, et al: Phase II study of a TLR-9 agonist (1018 ISS) with rituximab in patients with relapsed or refractory follicular lymphoma. Br J Haematol 146: 282-291, 2009.

11. Dovedi SJ, Melis MH, Wilkinson RW, Adlard AL, Stratford IJ, Honeychurch J and Illidge TM: Systemic delivery of a TLR7 agonist in combination with radiation primes durable antitumor immune responses in mouse models of lymphoma. Blood 121: 251-259, 2013.

12. Mason KA, Neal R, Hunter N, Ariga H, Ang K and Milas L: $\mathrm{CpG}$ oligodeoxynucleotides are potent enhancers of radio- and chemoresponses of murine tumors. Radiother Oncol 80: 192-198, 2006.

13. Schmidt-Wolf IG, Negrin RS, Kiem HP, Blume KG and Weissman IL: Use of a SCID mouse/human lymphoma model to evaluate cytokine-induced killer cells with potent antitumor cell activity. J Exp Med 174: 139-149, 1991.

14. Lu PH and Negrin RS: A novel population of expanded human $\mathrm{CD}^{+} \mathrm{CD}^{2} 6^{+}$cells derived from $\mathrm{T}$ cells with potent in vivo antitumor activity in mice with severe combined immunodeficiency. J Immunol 153: 1687-1696, 1994.

15. Hoyle C, Bangs CD, Chang P, Kamel O, Mehta B and Negrin RS: Expansion of Philadelphia chromosome-negative CD3(+) CD56(+) cytotoxic cells from chronic myeloid leukemia patients: In vitro and in vivo efficacy in severe combined immunodeficiency disease mice. Blood 92: 3318-3327, 1998.

16. Alvarnas JC, Linn YC, Hope EG and Negrin RS: Expansion of cytotoxic $\mathrm{CD}^{+} \mathrm{CD}^{+} 6^{+}$cells from peripheral blood progenitor cells of patients undergoing autologous hematopoietic cell transplantation. Biol Blood Marrow Transplant 7: 216-222, 2001.

17. Gao D, Diao Y, Li W, Gao N, Liu Y, Wang Z, Jiang W and Jin G: Toll-like receptor 7 inactive ligands enhanced cy tokine induction by conjugation to weak antigens. ChemMedChem 10: 977-980, 2015.

18. Pittari G, Filippini P, Gentilcore G, Grivel JC and Rutella S: Revving up natural killer cells and cytokine-induced killer cells against hematological malignancies. Front Immunol 6: 230, 2015.

19. Li Y, Schmidt-Wolf IG, Wu YF, Huang SL, Wei J, Fang J, Huang $\mathrm{K}$ and Zhou DH: Optimized protocols for generation of cord blood-derived cytokine-induced killer/natural killer cells. Anticancer Res 30: 3493-3499, 2010.

20. Deng QI, Bai X, Lv HR, Xiao X,Zhao MF and Li YM: Anti-CD20 antibody induces the improvement of cytokine-induced killer cell activity via the STAT and MAPK/ERK signaling pathways. Exp Ther Med 9: 1215-1222, 2015

21. Pievani A, Borleri G, Pende D, Moretta L, Rambaldi A, Golay J and Introna M: Dual-functional capability of $\mathrm{CD} 3{ }^{+} \mathrm{CD} 56^{+} \mathrm{CIK}$ cells, a T-cell subset that acquires $\mathrm{NK}$ function and retains TCR-mediated specific cytotoxicity. Blood 118: 3301-3310, 2011.

22. Abrahamsen IW, Sømme S, Heldal D, Egeland T, Kvale D and Tjønnfjord GE: Immune reconstitution after allogeneic stem cell transplantation: The impact of stem cell source and graft-versus-host disease. Haematologica 90: 86-93, 2005. 
23. Xu K, Li C, Pan X and Du B: Study of relieving graft-versus-host disease by blocking CD137-CD137 ligand costimulatory pathway in vitro. Int J Hematol 86: 84-90, 2007.

24. Lee M, Park CS, Lee YR, Im SA, Song S and Lee CK: Resiquimod, a TLR7/8 agonist, promotes differentiation of myeloid-derived suppressor cells into macrophages and dendritic cells. Arch Pharm Res 37: 1234-1240, 2014.

25. Richardt-Pargmann D, Wechsler M, Krieg AM, Vollmer J and Jurk M: Positive T cell co-stimulation by TLR7/8 ligands is dependent on the cellular environment. Immunobiology 216 : 12-23, 2011.
26. Ghosh TK, Mickelson DJ, Solberg JC, Lipson KE, Inglefield JR and Alkan SS: TLR-TLR cross talk in human PBMC resulting in synergistic and antagonistic regulation of type- 1 and 2 interferons, IL-12 and TNF-alpha. Int Immunopharmacol 7: 1111-1121, 2007. 27. Helms MW, Prescher JA, Cao YA, Schaffert S and Contag CH: IL-12 enhances efficacy and shortens enrichment time in cytokine-induced killer cell immunotherapy. Cancer Immunol Immunother 59: 1325-1334, 2010. 